Article

\title{
Factors Influencing the Adoption of Water Conservation Technologies by Smallholder Farmer Households in Tanzania
}

\author{
Srijna Jha ${ }^{1,2, *}$, Harald Kaechele ${ }^{1,3}$ and Stefan Sieber ${ }^{1,2}$ \\ 1 SusLAND: Sustainable Land Use in Developing Countries, Leibniz Centre for Agricultural Landscape \\ Research (ZALF), Eberswalder Straße 84, 15374 Müncheberg, Germany; harald.kaechele@zalf.de (H.K.); \\ stefan.sieber@zalf.de (S.S.) \\ 2 Department of Agricultural Economics, Humboldt University Berlin, Unter den Linden 6, \\ 10117 Berlin, Germany \\ 3 Department of Landscape Management and Nature Conservation, Eberswalde University for Sustainable \\ Development (HNEE), Schicklerstraße 5, 16225 Eberswalde, Germany \\ * Correspondence: srijna.jha@zalf.de; Tel.: +49-1636-960-469
}

Received: 20 November 2019; Accepted: 4 December 2019; Published: 13 December 2019

\begin{abstract}
In Tanzania, the increasing population coupled with climate change amplifies issues of food insecurity and negatively impacts the livelihoods of smallholder farmer households. To address these issues a range of water conservation techniques (WCTs) have been useful. However, the adoption of these WCTs in Tanzania has been limited due to many reasons. With the objective to better understand and identify the factors that significantly influence the adoption of WCTs in Tanzania, the study uses survey data from 701 smallholder farmer households and a bivariate logistic regression, to provide, for the first time, a comprehensive model for the adoption of WCTs in Tanzania that includes a range of individual, household, socio-economic, and farmer perception related variables (factors). The evaluation shows that 120 farmers $(17.12 \%)$ adopted WCTs and finds the farmer perceptions of rainfall instability, household wealth, and food security to be crucial. The results suggest that policy interventions should encourage conservation behavior (especially when the rainfall is perceived to be uncertain), emphasize the economic and food security-related benefits of adopting WCTs, include strategies that make adoption of WCTs attractive to female-led households, attempt to reach greater number of farmers via social networks and provide better access to public funds for farmers.
\end{abstract}

Keywords: decision-making; logit regression; farmer perceptions; social networks; public funds; water conservation adoption

\section{Introduction}

Owing to the topography and the changing climate, Sub-Saharan Africa (SSA) continues to face issues of food and water insecurity. Here chronic food insecurity, including the threat of famine, as well as malnourishment remains endemic. The most vulnerable are the small-holder farmers in rural areas where agrarian dependency and sensitivity to climate fluctuations are greater [1].

Tanzania, a predominantly agrarian economy, is one of the fastest-growing economies in SSA, but economic growth has not equally benefited all areas of the country [2]. Agricultural production accounts for nearly half of Tanzania's GDP [3], but rural areas, in particular, remain underdeveloped, productivity in agriculture lags and resources to improve the agricultural sector are needed [3-5]. Agriculture in Tanzania is predominantly rain-fed and directly dependent on annual rainy seasons [3]. A close relationship between variations in the amount of rainfall and economic growth is observed by various studies in Tanzania [3,6,7]. 
The high dependency on rain-fed agriculture is significantly impacted by the variability of rainfall (amount and distribution) in Tanzania [8]. These issues of high fluctuations in rainfall often manifest as droughts, famines, and floods, severely impacting the livelihoods and food security of the small-holder farmers [9-11]. For example, in Tanzania droughts and floods have been reported to cause failure and damage to crop and livestock leading to chronic food shortages [9-11]. The studies conducted by $[7,12]$ revealed that changes in rainfall patterns and amounts have and are predicted to lead to loss of crops and reduced livestock production. The agricultural sector suffers an estimated $\$ 200$ million in average annual losses because of weather-related incidents, particularly drought. In 2017, aggregate food prices increased by $12 \%$ due to drought-related food shortages. Another drought in 2009 resulted in the mortality of $80 \%$ of livestock in northern Tanzania [5]. Such extreme weather-related events and variable rainfall severely undermine the local and national development goals, and are predicted to continue to amplify issues of food security in the region [13].

Furthermore, in Tanzania the agriculture sector uses the vast majority of water resource available. Agriculture accounts for around $89 \%$ of total water used in Tanzania, which is high against a global average of $70 \%$ [5]. This makes water a critical input for Tanzania's economy, which heavily relies on the performance of the agricultural sector. In such a scenario of high dependence on agriculture, variability of rainfall and increasing demand for water, the adaptation measures towards ensuring water availability on farmland become critical. Water conservation methods seem to be effective for food security and reducing poverty in Tanzania [14]. A study by [15] found evidence of increased crop yields and long term financial profitability in the West Usambara highlands of Tanzania due to adoption of soil and water conservation technologies (WCTs). Another study by [16] in a semi-arid region of Tanzania showed that there is scope to improve grain yields, with the little available rainfall, through the adoption of techniques that promote water availability and retention within the field. In this context, WCTs are imperative for better agricultural production and food security in Tanzania.

Several efficient WCTs have been developed and utilized by farmers in the last decades. However, the adoption of these WCTs remains low in Tanzania $[17,18]$. The reasons for this are many and vary location to location. Relatively little work has been done to examine the adoption of WCTs at the farm and household levels in Tanzania. A study by [17] presents a model for farm-level adoption of soil and WCTs in the West Usambara highlands of Tanzania, with a focus on socio-economic factors. A study by [19] emphasizes the role of institutional and economic factors for the adoption of soil and WCTs in the semi-arid areas of Tanzania. Another study by [18] concludes that better agricultural water management can be achieved in Tanzania by matching adaptation measures to the farmers' local conditions. As study by [20] suggests a need for formal integration of sociologic, economic, and psychological variables in the adoption models. Whereas [21] argue that many factors affect the adoption decision, which may be determined by the historical, political, ecological, socio-cultural, and economic conditions. In this sense most adoption studies are limited and a comprehensive model to study adoption of WCTs at the household level in Tanzania does not exist and often focus on one or two dimensions (individual, household, social, economic, technological, environmental).

Furthermore, we found no adoption studies that included farmer perceptions, along with individual, household, and socio-economic factors, to explain the adoption process of WCTs by smallholder farmer households in Tanzania. The studies by [22,23] strongly argue to expand the range of independent variables used in the technology adoption models, and to include variables representing a farmer's subjective perceptions along with the more standard individual, household, and socio-economic variables. In [24], a strong case is made for a better and comprehensive understanding of farmer perceptions and associated constraints for the design and promotion of soil and WCTs. The authors suggest that the decision of a farmer to invest in soil and WCTs is influenced by the perceptions of the farmers, which, in turn, is driven by a range of institutional, socio-economic, biophysical, and attitude related factors.

Similar to [21,24], we argue that adoption studies that include farmer perceptions, along with other individual, household, and socio-economic conditions are useful for understanding the adoption 
of WCT and may guide management and policy interventions better than one-dimensional adoption models. Therefore, the study takes a broader approach and provides a framework for analysis that includes a wide range of factors that reflect the individual, household, and socio-economic characteristics of the farmers, along with factors that reflect farmer perceptions. The study poses two research questions:

1. What is the adoption level of WCTs?

2. What are the most significant variables (factors, drivers of adoption) associated with adoption of "water conservation technologies" in Tanzania?

The study contributes first by adding to the very limited literature on the adoption of WCTs by smallholder farmer households in Tanzania. Second, the analysis provides new evidence on the significance of factors related to farmer perceptions for the successful adoption of WCTs and its relevance for policy. Third, it includes a wide range of factors (individual, household, socio-economic) that may influence the adoption of WCTs, which allows the study to be adapted easily. Hence it provides a unique dataset, discusses implications for the adoption of WCTs from a unique multidimensional perspective, and provides a starting point for policy interventions to better manage adoption of WCTs amongst smallholder farmer households.

\section{Literature Review}

\subsection{Definition of Adoption}

Adoptions are the processes governing the utilization of innovations. Innovations are defined here as new methods, customs, or devices used to perform new tasks [25]. In defining "adoption", the study considers adoption to be a dichotomous variable [26]. A farmer is defined as an adopter if he or she has one or more WCTs implemented and functioning [27] at the time of the survey. The WCTs, as reported by the farmers, referred to here, include rooftop rainwater harvesting (RWH), micro-dam surface water runoff collection, on-farm runoff water harvesting (planting pits, furrows), and diversion of water (spate irrigation) (Appendix A). The farmers based on relevance for their agricultural systems selected these four WCTs. For the purpose of this study the adoption of any of these four WCTs was considered as adoption.

\subsection{Adoption Models}

The study considers the three adoption models-innovation diffusion model, economic constraints model, and user context model—proposed by [28]. The innovation diffusion model follows the work of [29]. The economic constraints model emphasizes that the resources the potential adopter have, often determines their adoption behavior. The user context model assumes that the potential adopter's agro-ecological, institutional, and socio-economic factors drive adoption behavior [28]. In line with the objectives, the economic constraints model and the user-context adoption model are of particular interest. The models allow for inclusion of the variables related to resources available and the seldom-studied perception of an individual farmer regarding their socio-economic status and environment. The models signify the role of farmers in the adoption process.

\subsection{Variables}

In general, literature shows adoption of WCTs to be a function of a multitude of variables (factors), which differ study to study. Based on the economic constraint and user-context adoption models, for the study, it is assumed that adoption behavior (action) is influenced by individual, household, socio-economic characteristics, and perceptions of the farmers. Each of these factors is assumed to influence the adoption process. 


\subsubsection{Individual and Household}

Age, health, gender of the head of the household, education, ability to read and write, and risk-taking attitude have been shown to be associated with adoption in numerous studies [30-35]. Most studies that have examined age as a determinant of water conservation have found that older people are more likely to be water conservers [36-38]. Poor health acts as a constraint and may result in low adoption rates of WCTs, since households may lose important labor due to illness [39]. Most studies show the gender of the head of the household to be positivity related (i.e., male-headed households are more likely to adopt new agricultural technologies compared to female-headed households) $[40,41]$. Inconsistencies emerge from the research investigating the impact of education on water conservation behavior. Some researchers report a positive relationship between education and water conservation [42-44]. Other researchers show an inverse relationship. In particular, they found that it is less educated individuals that show both more water conservation behavior and higher water conservation intentions [36,38]. Generally the ability to read and write allows the adopter access, comprehension, and deliberates the consequences of adoption of WCTs. As argued by [45], risk, uncertainty, and learning play a number of distinct roles in the process of adopting new technologies. Studies show risk aversion to be an important factor affecting adoption [46]. A few studies have found adoption to be strongly related to geographic location [39,47]. Household size facilitates the division of labor, investment, knowledge sharing, awareness, and experience required for the adoption process [48-51]. Household water consumption is inversely related to adoption [52] and there is a positive relationship between the number of residents and water use [36].

\subsubsection{Socio-Economic}

A wide range of social and economic parameters impact adoption. Social networks on the household level are important to adoption. They can be seen as a process of imitation of behavior, wherein contacts with others led to the spread of technology $[53,54]$. Social ties within and outside an organization provide extensiveness, quality, and diversity that may drive adoption behavior [55]. Several studies have found social networks to positively influence the adoption process [39,56-61]. Wealth and differential access to capital are often cited to explain different rates of adoption of WCTs. Credit constraints tend to negatively impact the adoption of WCTs, especially if a capital investment is required. Adoption behavior may not be affected by credit constraints if the adopter has other sources of finance, such as access to microcredits, public funds, and/or own savings [39,52,62-64]. Pieces of land owned or used by small-scale farmers (land fragmentation) could be a determinant of the adoption of land, soil, and water conservation measures [30]. Ownership of more pieces of land is associated with greater wealth and the increased availability of capital resources, which increases the likelihood of farmers making investments in land, soil, and water conservation measures [65]. Farm size is often cited as a crucial variable that impacts the adoption of agricultural technologies [66]. While some studies found a significant relationship between farm size and tractor adoption [67], others found no relation at all [68]. Literature shows a negative and significant effect of reliance on off-farm employment by poorer population segments. Higher opportunity costs of household labor are realized with the increased availability of off-farm work $[52,69]$. Results from studies that examine income stability as a determinant of water conservation behavior are consistent $[63,70]$. Research generally shows that individuals with a stable and/or high income conserve more water [71].

\subsubsection{Farmer Perceptions}

The diversity of activities, experiences, and observations from the past shape perceptions and influence actions. People's perception of climate change, the environment, and change in rainfall influences their level of concern, which affects their motivation to act [72]. In line with this assumption, some studies indicate that concern about climate change increases consumers' willingness to modify their behaviors [73]. The study of [74] sought to identify the relationship between specific 
knowledge of environmental problems and water conservation behavior, finding that individuals who reported greater awareness of environmental problems also reported greater conservation actions. Environmental knowledge has predictive power in terms of pro-environmental behavior [75]. A study by [76] found that when farmers perceive the rainfall to be getting less and unstably low they tend to adopt WCTs more. The study of [77] states that if rainfall instability is a continuing concern then farmers may adopt WCTs less. The perception of wealth, personal and household, is included to be an important variable for adoption decisions in developing countries [39]. Wealthy farmers may focus on other income-generating activities and they may give less attention to WCTs [78]. No studies have explored the impact of the farmers perception of his or her household food security on the adoption of WCTs. The studies of $[30,79]$ discuss the role of household food security on adoption, but do not relate it to farmer perceptions.

\section{Materials and Methods}

\subsection{Study Area and Data Collection}

Two districts in Tanzania, Morogoro and Dodoma (Figure 1), were selected because of having the highest rates of food insecurity in Tanzania, 38\% for Dodoma and 34\% for Morogoro [80]. The two regions also vary in their topography and environmental conditions. Morogoro has a semi-humid climate with an annual rainfall of $600-800 \mathrm{~mm}$. The region is diverse with flat plains, highlands, and dry alluvial valleys. The main crops are maize, sorghum, legumes, and rice, with partial livestock integration. Dodoma is the semi-arid region with an annual rainfall of 350-500 $\mathrm{mm}$ and mostly small hills and flat plains. The main crops are sorghum and millet, with extensive livestock integration [81]. Low yields and frequent crop failures due to climate change and limited use of agricultural technologies are reoccurring issues [82].

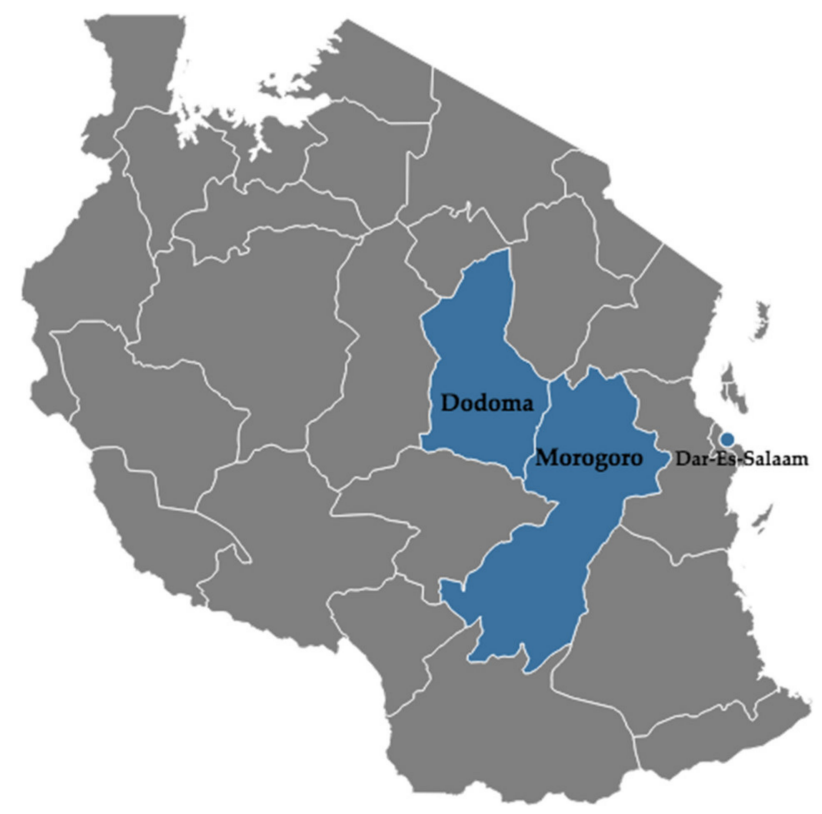

Figure 1. Map of Tanzania, showing the case study regions of Morogoro and Dodoma.

Data was collected as part of a larger survey carried out by the TRANSEC project [83] and analyzed using Stata IC 15.1. The questionnaire covered a wide range of issues including information on individual, household, and socio-economic background. Agricultural systems and farmer perceptions of climate change, their own household, and adaptation measures were also included. A total of 900 households were randomly selected in the Dodoma and Morogoro regions in rural Tanzania in 2016 [83]. Household heads were interviewed face to face and were all smallholder farms (under 2 ha). 
Some respondents did not answer all of the questions; therefore, only 701 datasets, where full information for all relevant variables for this study was available, were used. The group consisted of 329 farmers from Morogoro and 372 farmers from Dodoma, of which 542 were males and 159 were females. The average household size was 5 people. A comparison of the data analyzed to the excluded data showed no significant difference between the included and excluded datasets with respect to these key variables (age, gender, health, education). Thus, it was appropriately assumed that no systematic bias exists and that the included datasets remain representative of the larger sample.

\subsection{Model Selection and Adequacy}

Opting for the best fit, a logit model (regression) was used to analyze the adoption of WCTs in Tanzania. The logit model allows for the outcome to have a binary value (i.e., adoption happens or it does not (1 or 0)) [84]. In this study, farmers were classified as adopters and non-adopters of WCTs. A value of 1 was assigned to farmers that adopted WCTs and 0 to non-adopters. Hence, for our case the logit model had the obvious advantage and suited the research objectives. Two automated variable selections were done using the backward and forward method. Independent variables were added and removed one by one until all the independent variables included in the model were found to be significant. Both forward and backward selection methods resulted in the same set of variables to be included in the model. Hence the model is well specified. To estimate the goodness-of-fit we used the Hosmer-Lemeshow test. The $p$-value for our model is 0.6216 and; therefore, adequately fits the data. The rate of correct classification is estimated to be $85.73 \%$

\subsection{Empirical Model Specification}

The probability that a WCT will be adopted is defined as,

$$
\operatorname{Logit}(Y)=\alpha+\Sigma \beta_{1} X_{1}+\Sigma \beta_{2} X_{2} \ldots+\Sigma \beta_{n} X_{n}+\varepsilon_{i}
$$

Here adoption, " $Y$ ", is a dummy and dependent variable indicating the decision to adopt or not. $Y=$ dependent variable (adoption of water conservation measures), with $1=$ adopters and $0=$ non-adopter $\alpha=$ intercept $; \beta_{1}, \ldots, \beta_{\mathrm{n}}=$ coefficients of the independent variables indicating the influence of these variables on the likelihood of adoption; $X_{1}, \ldots, X_{19}=$ the independent variables. Appendix $B$ gives the definition and summary statistics of all the independent variables $\left(X_{1}\right.$ to $\left.X_{19}\right)$.

\subsection{Variable Specification and Expected Outcomes}

A range of individual, household, socio-economic, and farmer perception related variables were selected from literature to be included in the analysis (Appendix B). Variables such as education, loans (taken and given), and perception of personal wealth were found to be collinear to the ability to read and write, savings, and perception of household wealth, respectively, hence they were excluded from the analysis. The land owned and farm size was found to be homogenous (average was $0.97 \mathrm{ha}$ ), hence excluded from the analysis.

The expected effects of the independent variables included in the logit model for the adoption of WCTs by households are discussed and summarized in Table 1 . 
Table 1. The expected relationship between adoption of water conservation technologies (WCTs) and all independent variables.

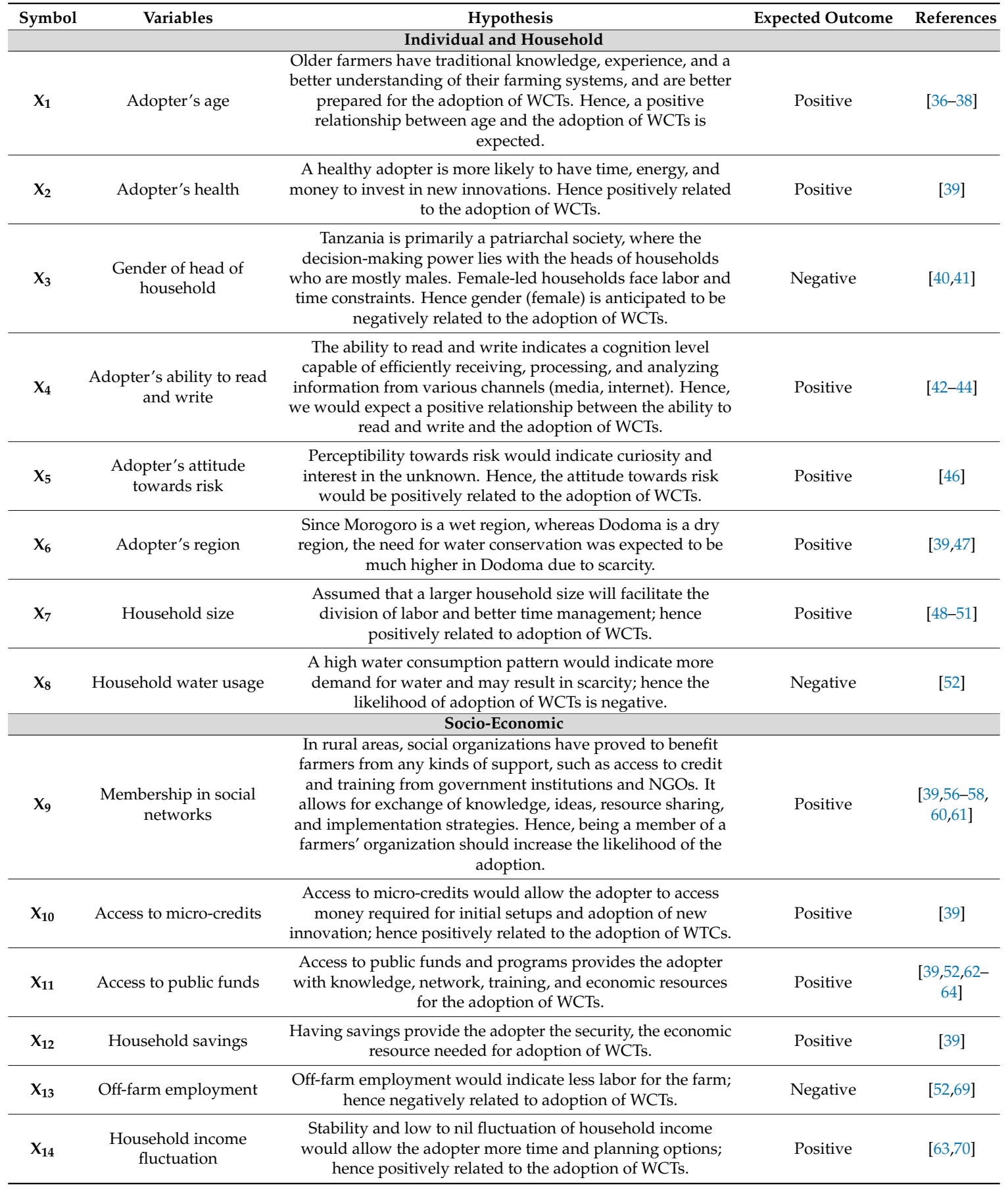


Table 1. Cont.

\begin{tabular}{|c|c|c|c|c|}
\hline Symbol & Variables & Hypothesis & Expected Outcome & References \\
\hline \multicolumn{5}{|c|}{ Farmer Perceptions } \\
\hline$X_{15}$ & $\begin{array}{l}\text { Perception of change in } \\
\text { rainfall }\end{array}$ & $\begin{array}{c}\text { "Some" rainfall although erratic maybe preferred to less or no } \\
\text { rainfall and that "consistent" rainfall may be preferred to less } \\
\text { rainfall and erratic rainfall; hence positively related to } \\
\text { adoption of WTCs. }\end{array}$ & Positive & [76] \\
\hline$X_{16}$ & $\begin{array}{l}\text { Perception of climate } \\
\text { change }\end{array}$ & $\begin{array}{l}\text { An adopter's observation and recognition of a changing } \\
\text { climate would indicate an awareness of the negative } \\
\text { consequences of CC on poverty and food security. It affects } \\
\text { the intention to behave and the attitude towards the behavior, } \\
\text { in our case water conservation practices (theory of reasoned } \\
\text { action); hence a perception of climate change and environment } \\
\text { both would be positively related to adoption of WTCs. }\end{array}$ & Positive & [73] \\
\hline$X_{17}$ & $\begin{array}{l}\text { Perception of change in } \\
\text { environment }\end{array}$ & $\begin{array}{l}\text { An adopter's observation and recognition of a changing } \\
\text { environment would indicate an awareness of the negative } \\
\text { consequences of degrading environment on poverty and food } \\
\text { security. It affects the intention to behave and the attitude } \\
\text { towards the behavior, in our case water conservation practices } \\
\text { (theory of reasoned action); hence a perception of climate } \\
\text { change and environment both would be positively related to } \\
\text { adoption of WTCs. }\end{array}$ & Positive & {$[74,75]$} \\
\hline$X_{18}$ & $\begin{array}{l}\text { Perception of household } \\
\text { wealth }\end{array}$ & $\begin{array}{c}\text { Better wealth status of the household would reflect a better } \\
\text { capacity to access, utilize and diversify input resources } \\
\text { needed for water conservation and positively related to } \\
\text { adoption of WCTs. }\end{array}$ & Positive & {$[39,78]$} \\
\hline$X_{19}$ & $\begin{array}{l}\text { Perception of household } \\
\text { food security }\end{array}$ & $\begin{array}{l}\text { Having a food secure household would allow the farmer to } \\
\text { think and invest in practices to enhance his food-value chain } \\
\text { system; hence positively related to the adoption of WCTs. }\end{array}$ & Positive & {$[30,79]$} \\
\hline
\end{tabular}

\section{Results}

Although $98 \%$ of the respondents in the study believed that the climate is changing, the rate of adoption of WCTs was at a low of $17.12 \%$. Amongst the adopters of WCTs, 39\% implemented on-farm runoff water harvesting, 35\% implemented rooftop rainwater harvesting, $18 \%$ implemented micro-dams/surface water runoff collection, and 9\% implemented diversion of water (spate irrigation). On-farm runoff water harvesting and rooftop rainwater harvesting were the most adopted WCTs. Whereas, the adoption of spate irrigation was found to be the most limited WCT.

Out of all the variables analyzed, the study finds six variables to have a significant impact on the adoption of WCTs in Tanzania. These are one individual and household variable- the gender of the head of household; two socio-economic variables-membership in social organizations and access to public funds; and three farmer perceptions related variables-farmer perception of change in rainfall, household wealth, and food security. This study finds that using a wide dataset to comprehensively study the adoption process of WCTs by smallholder farmers is useful. The results show that all, individual, household, socio-economic, and farmer perceptions factors are important to explain the adoption process of WCTs in the study region. Interestingly, of the six significant variables, we find three variables $(50 \%)$ to be related to farmer perceptions. This strongly suggests that the perceptions of the farmers' largely shape their adoption decisions and that a failure to consider the characteristics of the household and environment as perceived by the adopters (farmers) themselves may significantly hinder the adoption of WCTs.

The results of the logit model (Table 2) further show that the individual, household, socio-economic, and farmer perceptions related variables affect the adoption of WCTs differently. In line with the expected outcomes (Table 1), the study finds that women-led households have a lower likelihood of adoption of WCTs and those farmers who have access to social networks and public funds have a higher likelihood of adopting WCTs. In contrast to the expected outcome (Table 1), the study finds that a farmer's perception of rainfall instability has a significant negative influence on the adoption of WCTs. Whereas, a positive perception of household wealth and food security by the farmer has a significant positive influence on the adoption of WCTs, as expected. 
Table 2. Results of the logit model for the adoption of WCTs in Tanzania. Only the significant variables are shown.

\begin{tabular}{|c|c|c|c|}
\hline Significant Independent Variables & Coefficient & $p$-Value & Significance \\
\hline \multicolumn{4}{|c|}{ Individual and Household } \\
\hline Gender of head of household-female & -0.570 & 0.071 & * \\
\hline \multicolumn{4}{|c|}{ Socio-Economic } \\
\hline Membership in social network-yes & 2.065 & 0.000 & $* * *$ \\
\hline Access to public funds-yes & 1.298 & 0.000 & $* * *$ \\
\hline \multicolumn{4}{|c|}{ Farmer Perceptions } \\
\hline Perception of change in rainfall-more Erratic & -0.789 & 0.002 & $* * *$ \\
\hline Perception of change in rainfall—no change & -2.317 & 0.003 & $* * *$ \\
\hline Perception of household wealth—better off & 0.474 & 0.081 & * \\
\hline Perception of household food security-secure & 0.626 & 0.012 & ** \\
\hline Hosmer-Lemeshow test & \multicolumn{2}{|c|}{0.6216} & \\
\hline Pseudo R-squared & \multicolumn{2}{|c|}{0.2500} & \\
\hline Prediction statistics (correctly classified) & \multicolumn{2}{|c|}{$85.73 \%$} & \\
\hline
\end{tabular}

^ if the value is less than 0.05 , the model is a poor fit; ${ }^{* * *}$ Significant at $p<0.01(99 \%) ;{ }^{* *}$ Significant at $p<0.05(95 \%) ;$ * Significant at $p<0.1(90 \%)$ level.

The study finds no statistically significance for the individual and household variables related to adopter's age, health, ability to read and write, attitude towards risk, region, household size, household water usage, and adoption of WCTs in the study region. The same was found for socio-economic variables, such as access to microcredits, savings, off-farm employment, and household income fluctuations. Similarly, the farmers perception and recognition of the changing climate and environment has no statistical significance for the adoption of WCTs. Based on the literature review and general characteristics of the case study region we were expecting a positive (except household water usage and off-farm employment) relationship between these variables and the adoption of WCTs. However this was not observed in the sample analyzed.

In the next section, the six variables (factors) found to be significant for the adoption of WCTs in the case study region are discussed.

\subsection{Individual and Household}

\section{Gender of Head of Household}

Households with a female head are less likely to adopt WCTs as compared to households with male heads. We find that the WCTs in the case study region are labor intensive and need a sufficient input of time, which largely differs for males and females-the decision to spend time on activities related to conserving water vs. household activities. The labor and time constraint, hence, effects the relative advantage and compatibility of the WCTs with existing family and farming structures [22,85-87]. Several studies have investigated the association of the gender of the head of household and adoption. Most studies suggest that male-headed households are more likely to adopt new agricultural technologies compared to female-headed households [40,41]. In the study of [40] about improved maize technology in Ghana, they distinguish between the gender of the farmer and the gender of the head of the household. They find that the gender variable does not have any explanatory power regarding the decision to adopt, but the females living in female-headed households adopt at a lower rate than individuals in male-headed households. A study by [88], regarding peanut production in Eastern Uganda, finds that females living in female-headed households are less likely to adopt new varieties than females or males living in male-headed households. Their decision to adopt is affected by the available labor and time constraints. 


\subsection{Socio-Economic}

\subsubsection{Membership in Social Network}

The study finds that farmers who are part of a social network are more likely to adopt WCTs than farmers who are not part of social networks. Social networks enable the sharing of information, thus making the complexity of the WCTs more manageable and highlighting the benefits of conservation behavior $[85,86]$. Consistent with previous studies [39,56-58], membership in social networks is useful in explaining the adoption decision of WCTs. The study by [17] finds that farmers who are part of a group are more likely to adopt soil and WCTs in Tanzania. The authors suggest that membership in farmer groups and contact with extension agents positively influences the adoption of WCTs in Tanzania. The study of [60] finds that being part of a group enhances social networking, which in turn facilitates the sharing of experiences and building confidence in those farmers interested in the agricultural technologies [61].

\subsubsection{Access to Public Funds}

Farmers who have access to public programs and funds are more likely to adopt WCTs. We find that access to public funds and programs facilitate the initial adoption, provide for an information exchange network and institutional support. The public programs and funds provide economic support and may be used to shape attitudes towards adoption of WCTs. For example, public programs and funds, which support smallholder financing, can be an important adoption driver to overcome wealth constraints to investment in new technologies [62]. Once the initial adoption process is carried out, the understanding of the expected outcomes and benefits [22,85-87], of a WCT may become evident. Access to public programs or funds also indicates the motive of the government towards the farmers [89]. Similar to the findings of this study, [52,63,64] find that public programs can play a positive role in creating incentives for adoption. Studies by [90] in Ghana and [78] highlight the significance of financial inputs for the adoption of WCTs by smallholder farmers.

\subsection{Farmer Perceptions}

\subsubsection{Perception of Change in Rainfall}

Contrary to our hypothesis, when a farmer perceives that the rainfall is stagnant and/or getting more erratic (unclear onset and ending of rains), meaning that the regularity of rainfall is uncertain, they are less likely to adopt WCTs. It was assumed that an element of uncertainty would encourage the farmer to prepare for potential shocks; however, this was not the case. We find that if the farmers perceive that rainfall (water) is getting scarce then the efforts to conserve water decrease. We find that conservation behavior is hampered when the resource available is limited, that is, there is no water to conserve. Uncertainty in the future leads to a diversion from conservation actions due to a low perceived benefits [85,86]. In contrast a study by [76] in Ethiopia found a positive association between farmer perception of low and erratic rainfall and adoption of WCTs. In a study in Tanzania, [77] outlines that when farmers experience unreliable rainfall as a constant, they may become habituated and; therefore, not perceive the risk as urgent or immediate.

\subsubsection{Perception of Household Wealth Status}

Farmers whose household wealth status is better off than last year, and as compared to the rest of the village, are more likely to adopt WCTs. Perception of a better household wealth status reflects a better capacity to access, utilize, and diversify input resources needed for the adoption of WCTs. It leads to a sense of economic security which facilitates the investment and learning about the benefits of WCTs [22,85-87]. Similar to [39], we find that a perception of household wealth positively influences the adoption process of WCTs. While we found no other studies investigating adoption and the 
perceptions related to wealth, we did find two studies by $[56,91]$ who reported a positive influence of wealth on adoption in Tanzania and Ethiopia, respectively.

Other studies in Chile [52] and Ethiopia [92] have found that wealthier farmers were able to take on greater levels of risk, which gave them an advantage as adopters. In contrast, [77] finds that the wealthier farmers in Tanzania have more options to deal with water scarcity and low yields, which may make the issues of water conservation less important for them.

\subsubsection{Perception of Household Food Security}

Farmers who perceive their household to be food secure are more likely to adopt WCTs as compared to farmers who think they are food insecure. This is perhaps because enough food for the household members reflects a sufficient livelihood, which allows the farmer time and resources to test and understand the benefits of adopting WCTs. This, in turn, would form the behavior without the presence of significant stressors like food insecurity [22,85-87]. The impact of adoption of WCTs on food security has been studied extensively; however, no studies have explored the impact of farmer perception of household food security on the adoption of WCTs. The studies of [71,79] argue that stressors, such as food scarcity, have a negative impact on the adoption decision. Food insecure households must focus their efforts on coping strategies, rather than on conservation [93].

\section{Conclusions}

The study presents a model for the adoption of WCTs by smallholder farmers in Tanzania, based on data collected from 701 smallholder farmer households, and discusses the most significant factors that influence the adoption decisions of the farmers.

The adoption of WCTs in the case study area was at a low of $17 \%$ and emphasizes the urgency to comprehensively study adoption processes at the smallholder farmer household level.

The adoption of WCTs by smallholder farmer households in Tanzania can be effectively explained by integrating individual, household, socio-economic, and farmer perceptions related variables. The study finds that an integrated approach to study the adoption of WCTs better explains the adoption decisions, opportunities, and constraints that farmers face at the household level and allows for targeted agricultural management at the household level.

In order to ensure food and livelihood security for the most vulnerable, agriculture and policy interventions should better address gender-based disparities, such as labor and time constraints associated with adoption of WCTs. Furthermore, agriculture and policy interventions should aim to better reach, include, and integrate those farmers that are left behind (e.g., farmer's with no ties to social networks and farmer's with no access to public funds).

How farmers perceive the changes in rainfall, their household economy, and food security situation significantly influences their adoption decisions. Therefore, agriculture and policy interventions should emphasize the importance of adoption of WCTs in times when the farmers perceive the rainfall to be uncertain or scarce. Furthermore, agriculture and policy interventions should highlight the economic and food security related benefits that come from adoption of WCTs. The study provides evidence and determines that farmer perceptions are fundamental to studying and developing a well-targeted agricultural strategy at the household level; therefore, they should be included in adoption studies and further investigated. The study is limited by its scope, which focuses only on the determinants and not the effects of adoption of WCTs.

Author Contributions: Conceptualization, S.J.,H.K. and S.S.; Data Curation, S.J.; Formal Analysis, S.J.; Investigation, S.J.; Methodology, S.J.,H.K. and S.S.; Software, S.J.; Supervision, H.K. and S.S.; Validation, S.J., H.K. and S.S.; Visualization, S.J.; Writing-Original Draft, S.J.; Writing—Review and Editing, S.J., H.K. and S.S.

Funding: This research received no external funding.

Acknowledgments: We are thankful to the whole TRANSEC project team and SusLAND team for their administrative support and for providing necessary data and technical guidance. We are also grateful to the team at Sokoine University of Agriculture (SUA); for the provision of expertise; and technical support in the 
larger survey and data collection. We would also like to express our sincere thanks to the reviewers and peers who contributed their time to provide feedback and comments to revise the study.

Conflicts of Interest: The authors declare no conflicts of interest.

\section{Appendix A}

Types of WCTs used by the farmers and definitions.

1. Rooftop RWH involves three primary components: catchment, conveyance, and a collection device. The catchment is the rooftop where rainwater falls naturally. Rainwater drains down the slanted rooftop to the conveyance instruments, or gutters, at the base of the roof. These gutters transport the water from the rooftop to the collection device or storage tank [94].

2. Micro-dam surface water runoff harvesting is the collection of runoff (signifies the water running off surfaces on which rain has directly fallen) on small $\left(\sim 1-1000 \mathrm{~m}^{2}\right)$ treated catchments to channel it to a storage pit, adjacent cropping areas, or individual plants. The catchments are either modified by some kind of special tillage technique, earthen embankments, or masonry walls [94].

3. On-farm runoff water harvesting is the collection of runoff on a small catchment area to channel it using furrows to a planting pit for on-farm irrigation use. Furrows refer to a micro-catchment harvesting technique in which the rainfall water is harvested through the mulched ridges and the crop is planted in the furrows between the ridges [95]. Planting pits refer to ditches dug on farm with hand-hoe, to a depth exceeding $15 \mathrm{~cm}$, with no soil disturbance in between [96].

4. Spate irrigation has been defined as a system diverting flash floods from the riverbed via canals to fields that may be located some distance from the water source. The word "spate" refers to flood water originating from episodic rainfall in the upper part of river catchments, which in the lower part is diverted from ephemeral rivers and spread over agricultural land [97].

\section{Appendix B}

Definition and statistical summary of all the independent variables used in the logit model for household adoption of WCTs in Tanzania using 701 observations

\begin{tabular}{|c|c|c|c|c|}
\hline Symbol & Variables & Survey Question & Variable Type & Mean or Proportion \\
\hline \multicolumn{5}{|c|}{ Individual and Household } \\
\hline$X_{1}$ & Adopter's age & Age? & Continuous, 22 to 99 & 50.81 \\
\hline$X_{2}$ & Adopter's health status & How healthy is adopter? & $\begin{array}{l}\text { Categorical, } 1=\text { Sick, } \\
\begin{array}{c}2=\text { Can manage, } \\
3=\text { Healthy }\end{array}\end{array}$ & $\begin{array}{c}\text { Sick }=0.05, \\
\text { Can manage }=0.15, \text { Health } \\
=0.80\end{array}$ \\
\hline $\mathrm{X}_{3}$ & $\begin{array}{c}\text { Gender of head of } \\
\text { household }\end{array}$ & Gender? & $\begin{array}{c}\text { Categorical, } 0=\text { Male, } \\
1=\text { Female }\end{array}$ & $\begin{array}{c}\text { Male }=0.77 \\
\text { Female }=0.23\end{array}$ \\
\hline$X_{4}$ & $\begin{array}{l}\text { Adopter's Ability to read } \\
\text { and write }\end{array}$ & $\begin{array}{l}\text { Can the primary adopter } \\
\text { read and write? }\end{array}$ & $\begin{array}{c}\text { Binary, } 0=\text { Cannot read and } \\
\text { write, } \\
1=\text { Can read and write }\end{array}$ & $\begin{array}{l}\text { No }=0.33 \\
\text { Yes }=0.67\end{array}$ \\
\hline$X_{5}$ & $\begin{array}{c}\text { Adopter's risk taking } \\
\text { attitude }\end{array}$ & $\begin{array}{l}\text { Risk attitude (0: unwilling to } \\
\text { take risk, 3: fully prepared to } \\
\text { take risks) }\end{array}$ & $\begin{array}{l}\text { Ordinal, } 1=\text { Low } \\
\begin{array}{l}2=\text { Medium } \\
3=\text { High }\end{array}\end{array}$ & $\begin{array}{c}\text { Low }=0.22, \\
\text { Medium }=0.50, \\
\text { High }=0.28\end{array}$ \\
\hline$X_{6}$ & Adopter's Region & $\begin{array}{l}\text { Which region of Tanzania } \\
\text { does the respondent live and } \\
\text { farm in? }\end{array}$ & $\begin{array}{c}\text { Categorical, } 1=\text { Morogoro, } \\
2=\text { Dodoma }\end{array}$ & $\begin{array}{c}\text { Morogoro }=0.47 \\
\text { Dodoma }=0.53\end{array}$ \\
\hline$X_{7}$ & Household size & Household nucleus size? & Continuous, 0 to 10 & 4.59 \\
\hline$X_{8}$ & Household water usage & $\begin{array}{l}\text { Daily water use per } \\
\text { household in liter? }\end{array}$ & Continuous, 4 to 200 & 70.06 \\
\hline
\end{tabular}




\begin{tabular}{|c|c|c|c|c|}
\hline Symbol & Variables & Survey Question & Variable Type & Mean or Proportion \\
\hline \multicolumn{5}{|c|}{ Socio-Economic } \\
\hline$X_{9}$ & $\begin{array}{l}\text { Membership in social } \\
\text { and or political } \\
\text { organizations }\end{array}$ & $\begin{array}{c}\text { Member in } \\
\text { organizations/committees/and } \\
\text { political parties? }\end{array}$ & $\begin{array}{c}\text { Binary, } 0=\text { Not a member, } \\
1=\text { Yes, a member }\end{array}$ & $\begin{array}{l}\text { No }=0.56 \\
\text { Yes }=0.44\end{array}$ \\
\hline $\mathrm{X}_{10}$ & Access to microcredit & $\begin{array}{l}\text { Is anyone in the household } \\
\text { member of a } \\
\text { micro-credit group? }\end{array}$ & $\begin{array}{l}\begin{array}{l}\text { Binary, } 0=\text { Has no access to } \\
\text { microcredit, }\end{array} \\
1=\text { Has access to microcredit }\end{array}$ & $\begin{array}{l}\text { No }=0.91 \\
\text { Yes }=0.09\end{array}$ \\
\hline$x_{11}$ & Access to public funds & $\begin{array}{l}\text { Has any of household } \\
\text { received public transfers } \\
\text { (cash/in-kind) in ref. period? }\end{array}$ & $\begin{array}{c}\text { Binary, } 0=\text { Has no access to } \\
\text { public funds, } \\
1=\text { Has access to } \\
\text { public funds }\end{array}$ & $\begin{array}{l}\text { No }=0.72 \\
\text { Yes }=0.28\end{array}$ \\
\hline $\mathrm{X}_{12}$ & Household savings & Do you have any savings? & $\begin{array}{c}\text { Binary, } 0=\text { Has no savings } \\
1=\text { Has savings }\end{array}$ & $\begin{array}{l}\text { No }=0.23 \\
\text { Yes }=0.77\end{array}$ \\
\hline $\mathrm{X}_{13}$ & Off farm employment & $\begin{array}{l}\text { Anyone in household } \\
\text { engaged in non-farm } \\
\text { self-employment in ref. } \\
\text { period? }\end{array}$ & $\begin{array}{c}\text { Binary, } 0=\text { No, } \\
1=\text { Yes }\end{array}$ & $\begin{array}{l}\text { No }=0.64 \\
\text { Yes }=0.36\end{array}$ \\
\hline$X_{14}$ & $\begin{array}{l}\text { Household income } \\
\text { fluctuation }\end{array}$ & $\begin{array}{l}\text { How much did your } \\
\text { household income fluctuate } \\
\text { in } 3 \text { years? }\end{array}$ & $\begin{array}{c}\text { Ordinal, } 1=\text { Yes a bit, } \\
2=\text { Not at all } \\
3=\text { Yes a lot }\end{array}$ & $\begin{array}{l}\text { Yes a bit }=0.34 \\
\text { Not at all }=0.11 \\
\text { Yes a lot }=0.55\end{array}$ \\
\hline \multicolumn{5}{|c|}{ Farmer Perceptions } \\
\hline$X_{15}$ & $\begin{array}{l}\text { Perception of change in } \\
\text { rainfall }\end{array}$ & $\begin{array}{c}\text { Change in rainfall pattern } \\
\text { last } 3 \text { years? }\end{array}$ & $\begin{array}{c}\text { Continuous, } 1 \text { = Less rain, } \\
2 \text { = More erratic, } \\
3=\text { No change, } \\
4=\text { More rain }\end{array}$ & $\begin{array}{c}\text { Less }=0.38, \\
\text { Erratic }=0.40, \\
\text { No change }=0.13, \text { More }= \\
0.10\end{array}$ \\
\hline$X_{16}$ & $\begin{array}{l}\text { Perception of climate } \\
\text { change }\end{array}$ & $\begin{array}{l}\text { Do you think the climate } \\
\text { (weather) in general has } \\
\text { been changing in the past } \\
20 \text { years? }\end{array}$ & $\begin{array}{c}\text { Binary, } 0=\text { Climate is } \\
\text { not changing, } \\
1=\text { Yes, climate is changing }\end{array}$ & $\begin{array}{l}\text { No }=0.02 \\
\text { Yes }=0.98\end{array}$ \\
\hline $\mathrm{X}_{17}$ & $\begin{array}{l}\text { Perception of } \\
\text { environmental change }\end{array}$ & $\begin{array}{c}\text { Do you think, your } \\
\text { environment has changed in } \\
\text { past } 20 \text { years? }\end{array}$ & $\begin{array}{c}\text { Binary, } 0=\text { Environment is } \\
\text { not changing, } \\
1=\text { Yes, environment } \\
\text { is changing }\end{array}$ & $\begin{array}{l}\text { No }=0.08 \\
\text { Yes }=0.92\end{array}$ \\
\hline$X_{18}$ & $\begin{array}{l}\text { Perception of household } \\
\text { wealth status }\end{array}$ & $\begin{array}{l}\text { Do you think your } \\
\text { household is better off than } \\
\text { last year? }\end{array}$ & $\begin{array}{c}\text { Ordinal, } 1=\text { Worse off, } 2= \\
\text { Same, } 3=\text { Better off }\end{array}$ & $\begin{array}{c}\text { Worse }=0.51, \text { Same }=0.21, \\
\text { Better }=0.28\end{array}$ \\
\hline$X_{19}$ & $\begin{array}{l}\text { Perception of household } \\
\text { food security }\end{array}$ & $\begin{array}{l}\text { Do you consider your } \\
\text { household being } \\
\text { "food secure"? }\end{array}$ & $\begin{array}{c}\text { Binary, } 0=\text { Not food secure, } \\
1=\text { Yes, food secure }\end{array}$ & $\begin{array}{l}\text { No }=0.52 \\
\text { Yes }=0.48\end{array}$ \\
\hline
\end{tabular}

\section{References}

1. Williams, P.A.; Crespo, O.; Abu, M.; Simpson, N.P. A systematic review of how vulnerability of smallholder agricultural systems to changing climate is assessed in Africa. Environ. Res. Lett. 2018, 13, 103004. [CrossRef]

2. Pelizzo, R.; Kinyondo, A. Growth, Employment, Poverty and Inequality in Tanzania. JPAS 2018, 13, 3. [CrossRef]

3. Noel, S. The Economics of Climate Change in Tanzania Water Resources; Institute of Resource Assessment, University of Dar es Salaam: Dar es Salaam, Tanzania, 2012.

4. Drakenberg, O.; Ek, G.; Fernqvist, K.W. Environmental and Climate Change Policy Brief_Tanzania; Sidas Technical report for Sida Helpdesk for Environment and Climate Change; Sida-the Swedish International Development Cooperation Agency: Stockholm, Sweden, 30 May 2016.

5. The World Bank Water Stress Could Hurt Tanzania's Growth and Poverty Reduction Efforts-New World Bank Report. Available online: https://www.worldbank.org/en/news/press-release/2017/11/06/water-stress-couldhurt-tanzanias-growth-and-poverty-reduction-efforts---new-world-bank-report (accessed on 2 May 2019).

6. Magehema, A.; Chang, L.; Mkoma, S. Implication of rainfall variability on maize production in Morogoro, Tanzania. Int. J. Environ. Sci. 2014, 4, 1077-1086.

7. Afifi, T.; Liwenga, E.; Kwezi, L. Rainfall-induced crop failure, food insecurity and out-migration in Same-Kilimanjaro, Tanzania. Clim. Dev. 2014, 6, 53-60. [CrossRef] 
8. Kijazi, A.L.; Reason, C.J.C. Relationships between intraseasonal rainfall variability of coastal Tanzania and ENSO. Theor. Appl. Climatol. 2005, 82, 153-176. [CrossRef]

9. Jackson, S.; Claude, G.M.; Godfrey, F.K. Impacts of Climate Change, Variability and Adaptation Strategies on Agriculture in Semi Arid Areas of Tanzania: The Case of Manyoni District in Singida Region, Tanzania. Afr. J. Environ. Sci. Technol. 2018, 12, 323-334. [CrossRef]

10. Levira, P.W. Climate change impact in agriculture sector in Tanzania and its mitigation measure. IOP Conf. Ser. Earth Environ. Sci. 2009, 6, 372049. [CrossRef]

11. Majule, A.E.; Rioux, J.; Mpanda, M.; Karttunen, K. Review of Climate Change Mitigation in Agriculture in Tanzania; Food and Agricultural Organization of United Nations: Rome, Italy, 2014.

12. Rowhani, P.; Lobell, D.B.; Linderman, M.; Ramankutty, N. Climate variability and crop production in Tanzania. Agric. For. Meteorol. 2011, 151, 449-460. [CrossRef]

13. Shayo, C.M. Forests, Rangelands and Climate Change Adaptation in Tanzania. In Proceedings of the Workshop on Forests, Rangelands and Climate Change Adaptation, Johannesburg, South Africa, 17-19 June 2013; pp. 1-14.

14. FAO Water for Sustainable Food and Agriculture A Report Produced for the G20 Presidency of Germany; FAO: Rome, Italy, 2017.

15. Tenge, A.J.; De Graaff, J.; Hella, J.P. Financial efficiency of major soil and water conservation measures in West Usambara highlands, Tanzania. Appl. Geogr. 2005, 25, 348-366. [CrossRef]

16. Makurira, H.; Savenije, H.H.G.; Uhlenbrook, S.; Rockström, J.; Senzanje, A. The effect of system innovations on water productivity in subsistence rainfed agricultural systems in semi-arid Tanzania. Agric. Water Manag. 2011, 98, 1696-1703. [CrossRef]

17. Tenge, A.J.; De Graaff, J.; Hella, J.P. Social and economic factors affecting the adoption of soil and water conservation in West Usambara highlands, Tanzania. L. Degrad. Dev. 2004, 25, 348-366. [CrossRef]

18. Kimaro, J. A Review on Managing Agroecosystems for Improved Water Use Efficiency in the Face of Changing Climate in Tanzania. Adv. Meteorol. 2019, 2019, 1-12. [CrossRef]

19. Boyd, C.; Turton, C.; Hatibu, N.; Mahoo, H.F.; Lazaro, E.; Rwehumbiza, F.B.; Okubal, P.; Makumbi, M. The contribution of soil and water conservation to sustainable livelihoods in semi-arid areas of Sub-Saharan Africa. Agric. Res. Ext. Netw. Pap. 2000, 102, 1-16.

20. Edwards-Jones, G. Modelling farmer decision-making: Concepts, progress and challenges. Anim. Sci. 2006, 82, 783-790. [CrossRef]

21. Kideghesho, J.R.; Røskaft, E.; Kaltenborn, B.P. Factors influencing conservation attitudes of local people in Western Serengeti, Tanzania. Biodivers. Conserv. 2007, 16, 2213-2230. [CrossRef]

22. Adesina, A.A.; Baidu-Forson, J. Farmers' perceptions and adoption of new agricultural technology: evidence from analysis in Burkina Faso and Guinea, West Africa. Agric. Econ. 1995, 13, 1-9. [CrossRef]

23. Rahm, M.R.; Huffman, W.E. The Adoption of Reduced Tillage: The Role of Human Capital and Other Variables: Reply. Am. J. Agric. Econ. 1986, 66, 405-413. [CrossRef]

24. Moges, D.M.; Taye, A.A. Determinants of farmers' perception to invest in soil and water conservation technologies in the North-Western Highlands of Ethiopia. Int. Soil Water Conserv. Res. 2017, 5, 56-61. [CrossRef]

25. Sunding, D.; Zilberman, D. The agricultural innovation process: Research and technology adoption in a changing agricultural sector. Handb. Agric. Econ. 2001, 1, 207-261.

26. Lin, J.Y. Education and Innovation Adoption in Agriculture: Evidence from Hybrid Rice in China. Am. J. Agric. Econ. 1991, 73, 713-723. [CrossRef]

27. Doss, C.R. Analyzing technology adoption using microstudies: Limitations, challenges, and opportunities for improvement. Agric. Econ. 2006, 34, 207-219. [CrossRef]

28. Negatu, W.; Parikh, A. The impact of perception and other factors on the adoption of agricultural technology in the Moret and Jiru Woreda (district) of Ethiopia. Agric. Econ. 1999, 21, 205-216. [CrossRef]

29. Rogers, E.M. Diffusion of Innovations, 4th ed; Simon and Schuster: New York, NY, USA, 2010; ISBN 0-02-926671-8.

30. Mango, N.; Makate, C.; Tamene, L.; Mponela, P.; Ndengu, G. Awareness and adoption of land, soil and water conservation practices in the Chinyanja Triangle, Southern Africa. Int. Soil Water Conserv. Res. 2017, 5, 122-129. [CrossRef] 
31. Willis, R.M.; Stewart, R.A.; Panuwatwanich, K.; Williams, P.R.; Hollingsworth, A.L. Quantifying the influence of environmental and water conservation attitudes on household end use water consumption. J. Environ. Manag. 2011, 92, 1996-2009. [CrossRef]

32. Sidibé, A. Farm-level adoption of soil and water conservation techniques in northern Burkina Faso. Agric. Water Manag. 2005, 71, 211-224. [CrossRef]

33. Campbell, H.E.; Johnson, R.M.; Larson, E.H. Prices, devices, people, or rules: The relative effectiveness of policy instruments in water conservation. Rev. Policy Res. 2004, 21, 637-662. [CrossRef]

34. Berk, R.A.; Schulman, D.; McKeever, M.; Freeman, H.E. Measuring the impact of water conservation campaigns in California. Clim. Change 1993, 24, 233-248. [CrossRef]

35. Hamilton, L.C. Saving water: A causal model of household conservation. Sociol. Perspect. 1983, 26, 355-374. [CrossRef]

36. Gregory, G.D.; Di Leo, M. Repeated Behavior and Environmental Psychology: The Role of Personal Involvement and Habit Formation in Explaining Water Consumption. J. Appl. Soc. Psychol. 2003, 33, 1261-1296. [CrossRef]

37. Russell, S.; Fielding, K. Water demand management research: A psychological perspective. Water Resour. Res. 2010, 46, 1-12. [CrossRef]

38. Clark, C.F.; Kotchen, M.J.; Moore, M.R. Internal and external influences on pro-environmental behavior: Participation in a green electricity program. J. Environ. Psychol. 2003, 23, 237-246. [CrossRef]

39. Abdulai, A.; Huffman, W. The Adoption and Impact of Soil and Water Conservation Technology: An Endogenous Switching Regression Application. Land Econ. 2015, 90, 26-43. [CrossRef]

40. Doss, C.R. Designing agricultural technology for African women farmers: Lessons from 25 years of experience. World Dev. 2001, 29, 2075-2092. [CrossRef]

41. Kumar, S.K. Adoption of hybrid maize in Zambia: effects on gender roles, food consumption, and nutrition. Food Nutr. Bull. 1995, 16, 1-3. [CrossRef]

42. De Oliver, M. Attitudes and inaction. A case study of the manifest demographics of urban water conservation. Environ. Behav. 1999, 31, 372-394. [CrossRef]

43. Gilg, A.; Barr, S. Behavioural attitudes towards water saving? Evidence from a study of environmental actions. Ecol. Econ. 2006, 57, 400-414. [CrossRef]

44. Lam, S.P. Predicting intention to save water: Theory of planned behavior, response efficacy, vulnerability, and perceived efficiency of alternative solutions. J. Appl. Soc. Psychol. 2006, 36, 2803-2824. [CrossRef]

45. Marra, M.; Pannell, D.J.; Abadi Ghadim, A. The economics of risk, uncertainty and learning in the adoption of new agricultural technologies: Where are we on the learning curve? Agric. Syst. 2003, 75, 215-234. [CrossRef]

46. Canales, E.; Bergtold, J.S.; Williams, J.; Peterson, J. Estimating farmers ' risk attitudes and risk premiums for the adoption of conservation practices under different contractual arrangements: A stated choice experiment. In Proceedings of the AAEA \& WAEA Joint Annual Meeting; Agricultural and Applied Economics Association, Western Agricultural Economics Association, San Francisco, CA, USA, 26-28 July 2015.

47. Lesch, W.C.; Wachenheim, C.J. Factors Influencing Conservation Practice Adoption in Agriculture: A Review of the Literature. Agribus. Appl. Econ. Rep. 2014. [CrossRef]

48. Boyer, T.A.; Kanza, P.; Ghimire, M.; Moss, J.Q. Household Adoption of Water Conservation and Resilience Under Drought: The Case of Oklahoma City. Water Econ. Policy 2015, 1, 1550005. [CrossRef]

49. Asfaw, D.; Neka, M. Factors affecting adoption of soil and water conservation practices: The case of Wereillu Woreda (District), South Wollo Zone, Amhara Region, Ethiopia. Int. Soil Water Conserv. Res. 2017, 5, 273-279. [CrossRef]

50. Millock, K.; Nauges, C. Household adoption of water-efficient equipment: The role of socio-economic factors, environmental attitudes and policy. Environ. Resour. Econ. 2010, 46, 539-565. [CrossRef]

51. Syme, G.J.; Shao, Q.; Po, M.; Campbell, E. Predicting and understanding home garden water use. Landsc. Urban Plan. 2004, 68, 121-128. [CrossRef]

52. Jara-Rojas, R.; Bravo-Ureta, B.E.; Díaz, J. Adoption of water conservation practices: A socioeconomic analysis of small-scale farmers in Central Chile. Agric. Syst. 2012, 110, 54-62. [CrossRef]

53. Nyangena, W. Social determinants of soil and water conservation in rural Kenya. Environ. Dev. Sustain. 2008, 10, 745-767. [CrossRef] 
54. Mazzucato, V.; Niemeijer, D. The cultural economy of soil and water conservation: Market principles and social networks in Eastern Burkina Faso. Dev. Change 2000, 31, 831-855. [CrossRef]

55. Greenhalgh, T.; Robert, G.; Macfarlane, F.; Bate, P.; Kyriakidou, O. Diffusion of innovations in service organizations: Systematic review and recommendations. Milbank Q. 2004, 82, 581-629. [CrossRef]

56. Kassie, M.; Jaleta, M.; Shiferaw, B.; Mmbando, F.; Mekuria, M. Adoption of interrelated sustainable agricultural practices in smallholder systems: Evidence from rural Tanzania. Technol. Forecast. Soc. Change 2013, 80, 525-540. [CrossRef]

57. Di Falco, S.; Veronesi, M. Managing Environmental Risk in Presence of Climate Change: The Role of Adaptation in the Nile Basin of Ethiopia. Environ. Resour. Econ. 2014, 57, 553-577. [CrossRef]

58. Abdulai, A.N. Impact of conservation agriculture technology on household welfare in Zambia. Agric. Econ. 2016, 47, 729-741. [CrossRef]

59. De Graaff, J.; Amsalu, A.; Bodnár, F.; Kessler, A.; Posthumus, H.; Tenge, A. Factors influencing adoption and continued use of long-term soil and water conservation measures in five developing countries. Appl. Geogr. 2008, 28, 271-280. [CrossRef]

60. Bandiera, O.; Rasul, I. Social networks and technology adoption in Northern Mozambique. Econ. J. 2006, 116, 869-902. [CrossRef]

61. Kassie, M.; Teklewold, H.; Jaleta, M.; Marenya, P.; Erenstein, O. Understanding the adoption of a portfolio of sustainable intensification practices in eastern and southern Africa. Land Use Policy 2015, 42, 400-411. [CrossRef]

62. Drechsel, P.; Olaleye, A.; Adeoti, A.; Thiombiano, L.; Barry, B.; Vohland, K. Adoption driver and constraints of resource conservation technologies in sub-saharan Africa. Berlin: FAO, IWMI, Humbold Universitaet, 2005; Unpublished work.

63. Traore, N.; Landry, R.; Amara, N. On-Farm Adoption of Conservation Practices: The Role of Farm and Farmer Characteristics, Perceptions, and Health Hazards. Land Econ. 1998, 74, 114-127. [CrossRef]

64. Kassam, A.; Friedrich, T.; Shaxson, F.; Bartz, H.; Mello, I.; Kienzle, J.; Pretty, J. The spread of Conservation Agriculture: policy and institutional support for adoption and uptake. Field Act. Sci. Rep. J. Field Act. 2014, 7, 1-12.

65. Tadesse, M.; Belay, K. Factors influencing adoption of soil conservation measures in Southern Ethiopia: The case of Gununo area. J. Agric. Rural Dev. Trop. Subtrop. 2004, 105, 49-62.

66. Feder, G.; Just, R.E.; Zilberman, D. Adoption of agricultural innovations in developing countries: a survey. Econ. Dev. Cult. Chang. 1985, 33, 255-298. [CrossRef]

67. Tripathi, R.S.; Binswanger, H.P. The economics of tractors in South Asia; an analytical review. Am. J. Agric. Econ. 1979, 61, 581. [CrossRef]

68. Doss, C.; Mwangi, W.; Verkuijl, H.; De Groote, H. Adoption of Maize and Wheat Technologies in Eastern Africa: A Synthesis of The Findings of 22 Case Studies; CIMMYT: Mexico City, Mexico, 2003.

69. Giller, K.E.; Andersson, J.A.; Corbeels, M.; Kirkegaard, J.; Mortensen, D.; Erenstein, O.; Vanlauwe, B. Beyond conservation agriculture. Front. Plant Sci. 2015, 6, 870. [CrossRef]

70. Liu, T.; Bruins, R.J.F.; Heberling, M.T. Factors influencing farmers' adoption of best management practices: A review and synthesis. Sustainability 2018, 10, 432. [CrossRef]

71. Rasoulkhani, K.; Logasa, B.; Reyes, M.P.; Mostafavi, A. Understanding fundamental phenomena affecting the water conservation technology adoption of residential consumers using agent-based modeling. Water 2018, 10, 993. [CrossRef]

72. Swim, J.; Clayton, S.; Doherty, T.; Gifford, R.; Howard, G.; Reser, J.P.; Stern, P.C.; Weber, E.U. Psychology and Global Climate Change: Addressing a Multi-faceted Phenomenon and Set of Challenges A. Am. Psychol. 2009, 66, 241-250. [CrossRef]

73. Semenza, J.C.; Hall, D.E.; Wilson, D.J.; Bontempo, B.D.; Sailor, D.J.; George, L.A. Public perception of climate change voluntary mitigation and barriers to behavior change. Am. J. Prev. Med. 2008, 35, 479-487. [CrossRef]

74. Clark, W.A.; Finley, J.C. Determinants of water conservation intention in Blagoevgrad, Bulgaria. Soc. Nat. Resour. 2007, 20, 613-627. [CrossRef]

75. Kaiser, F.G.; Wölfing, S.; Fuhrer, U. Environmental attitude and ecological behaviour. J. Environ. Psychol. 1999, 19, 1-19. [CrossRef] 
76. Kahsay, H.T.; Guta, D.D.; Birhanu, B.S.; Gidey, T.G. Farmers' Perceptions of Climate Change Trends and Adaptation Strategies in Semiarid Highlands of Eastern Tigray, Northern Ethiopia. Adv. Meteorol. 2019, 2019, 1-13. [CrossRef]

77. Slegers, M.F.W. "If only it would rain": Farmers' perceptions of rainfall and drought in semi-arid central Tanzania. J. Arid Environ. 2008, 72, 2106-2123. [CrossRef]

78. Teshome, A.; de Graaff, J.; Kassie, M. Household-Level Determinants of Soil and Water Conservation Adoption Phases: Evidence from North-Western Ethiopian Highlands. Environ. Manag. 2016, 57, 620-636. [CrossRef]

79. Karki, L.B.; Bauer, S. Assessment of impact of project intervention and factors determining technology adoption at small farm households level. In Proceedings of the The Deutscher Tropentag, Berlin, Germany, 5-7 October 2004.

80. URT. Tanzania National Sample Census of Agriculture 2007/2008 Small Holder Agriculture: Regional Report-Singida Region; United Republic of Tanzania, Ministry of Agriculture, Food Security and Cooperatives, Ministry of Livestock Development and Fisheries, Ministry of Water and Irrigation, Ministry of Agriculture, Livestock and Environment: Zanzibar City, Tanzania, April 2012.

81. Graef, F.; Sieber, S.; Mutabazi, K.; Asch, F.; Biesalski, H.K.; Bitegeko, J.; Bokelmann, W.; Bruentrup, M.; Dietrich, O.; Elly, N.; et al. Framework for participatory food security research in rural food value chains. Glob. Food Sec. 2014, 3, 8-15. [CrossRef]

82. Habtemariam, L.T.; Mgeni, C.P.; Mutabazi, K.D.; Sieber, S. The farm income and food security implications of adopting fertilizer micro-dosing and tied-ridge technologies under semi-arid environments in central Tanzania. J. Arid Environ. 2019, 166, 60-67. [CrossRef]

83. Trans-SEC - Innovating Strategies to safeguard Food Security using Technology and Knowledge Transfer: A people-centred Approach. Available online: http://www.trans-sec.org/ (accessed on 29 April 2019).

84. Shakya, P.B.; Flinn, J.C. Adoption of modern varieties and fertilizer use on rice in the eastern tarai of Nepal. J. Agric. Econ. 1985, 36, 409-419. [CrossRef]

85. Fishbein, M.; Ajzen, I. Belief, Attitude, Intention and Behaviour; Addison-Wesley: Boston, MA, USA, 1975; ISBN 0201020890.

86. Hill, R.J.; Fishbein, M.; Ajzen, I. Belief, Attitude, Intention and Behavior: An Introduction to Theory and Research. Contemp. Sociol. 1977, 6, 244. [CrossRef]

87. Lewin, K. Defining the "field at a given time" . Psychol. Rev. 1943, 50, 292-310. [CrossRef]

88. Tanellari, E.; Kostandini, G.; Bonabana-Wabbi, J.; Murray, A. Gender impacts on adoption of new technologies: the case of improved groundnut varieties in Uganda. Afr. J. Agric. Resour. Econ. 2014, 9, 1-9.

89. Wolka, K. Effect of soil and water conservation measures and challenges for its adoption: Ethiopia in focus. J. Environ. Sci. Technol. 2014, 7, 185-199. [CrossRef]

90. Darkwah, K.A.; Kwawu, J.D.; Agyire-Tettey, F.; Sarpong, D.B. Assessment of the determinants that influence the adoption of sustainable soil and water conservation practices in Techiman Municipality of Ghana. Int. Soil Water Conserv. Res. 2019, 7, 248-257. [CrossRef]

91. Teklewold, H.; Kassie, M.; Shiferaw, B. Adoption of multiple sustainable agricultural practices in rural Ethiopia. J. Agric. Econ. 2013, 64, 597-623. [CrossRef]

92. Anley, Y.; Bogale, A.; Haile-Gabriel, A. Adoption decision and use intensity of soil and water conservation measures by smallholder subsistence farmers in Dedo district, Western Ethiopia. L. Degrad. Dev. 2007, 18, 289-302. [CrossRef]

93. Dil Farzana, F.; Rahman, A.S.; Sultana, S.; Raihan, M.J.; Haque, M.A.; Waid, J.L.; Choudhury, N.; Ahmed, T. Coping strategies related to food insecurity at the household level in Bangladesh. PLoS ONE 2017, 12, 0171411. [CrossRef]

94. Beckers, B.; Berking, J.; Schütt, B. Ancient Water Harvesting Methods in the Drylands of the Mediterranean and Western Asia. eTopoi. J. Anc. Stud. 2013, 2, 145-164.

95. Gan, Y.; Siddique, K.H.M.; Turner, N.C.; Li, X.G.; Niu, J.Y.; Yang, C.; Liu, L.; Chai, Q. Ridge-Furrow Mulching Systems-An Innovative Technique for Boosting Crop Productivity in Semiarid Rain-Fed Environments. In Advances in Agronomy; Elsevier: Amsterdam, The Netherlands, 2013; pp. 429-476. ISBN 9780124059429. 
96. Rockström, J.; Kaumbutho, P.; Mwalley, J.; Nzabi, A.W.; Temesgen, M.; Mawenya, L.; Barron, J.; Mutua, J.; Damgaard-Larsen, S. Conservation farming strategies in East and Southern Africa: Yields and rain water productivity from on-farm action research. Soil Tillage Res. 2009, 103, 23-32. [CrossRef]

97. Komakech, H.C.; Mul, M.L.; Van Der Zaag, P.; Rwehumbiza, F.B.R. Water allocation and management in an emerging spate irrigation system in Makanya catchment, Tanzania. Agric. Water Manag. 2011, 98, 1719-1726. [CrossRef]

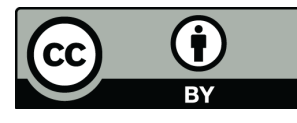

(C) 2019 by the authors. Licensee MDPI, Basel, Switzerland. This article is an open access article distributed under the terms and conditions of the Creative Commons Attribution (CC BY) license (http://creativecommons.org/licenses/by/4.0/). 